\title{
Impact of different drying parameters on color, $\beta$-carotene, antioxidant activity and minerals of apricot (Prunus armeniaca $\mathrm{L}$.)
}

\author{
Bige İNCEDAYI ${ }^{1}$, Canan Ece TAMER ${ }^{1}$, Gülşah Özcan SINIR ${ }^{1}$, Senem SUNA ${ }^{1 *}$, Ömer Utku ÇOPUR ${ }^{1}$
}

\begin{abstract}
Apricot is one of the fruits dried by using different methods, such as sun, convective or microwave drying. The effects of drying methods on the components of this fruit differ depending upon the temperature or time parameters. In this research, the impacts of convective, microwave and microwave-convective drying techniques on color, $\beta$-carotene, minerals and antioxidant activity of apricots were investigated. The color values $\left(L^{*}, b^{*}, \Delta E_{\mathrm{ab},} \mathrm{h}^{\circ}\right.$ and $\left.\mathrm{C}_{\mathrm{ab}}^{*}\right)$ of dried fruit were decreased, while the $a^{*}$ values increased. Compared with a fresh sample, the dried apricots showed a 1.4-3.9-fold proportional increase in $\beta$-carotene based on the increment of dry matter. The samples dried at high temperature and microwave levels, at $75^{\circ} \mathrm{C}+90$ watt and $75^{\circ} \mathrm{C}+160$ watt, showed lower antioxidant activity. Of the different drying treatments, the microwave-convective method $\left(50{ }^{\circ} \mathrm{C}+160\right.$ watt) obtained a higher $\beta$-carotene content while maintaining antioxidant activity with a short drying time.
\end{abstract}

Keywords: apricot; drying; color; $\beta$-carotene; antioxidant activity.

Practical Application: This paper presents different drying methods of apricots in addition to optimization of the power level and temperature conditions. These methods make it possible to select the best way to provide high quality and nutritional dried apricots.

\section{Introduction}

Many types of fruit must be processed to maintain their quality because they are seasonal, and their shelf life is limited (Ścibisz \& Mitek, 2007). The apricot is one of these fruits due to its high respiration rate and rapid ripening process (Fratianni et al., 2013). To extend the shelf life of this fruit, several conservation methods have been improved, such as drying, canning, packing in a controlled/modified atmosphere, and processing to produce fruit juice, fruit puree, jam, marmalade or pestil (Elmac1 et al., 2008; Özler et al., 2008; Jiménez et al., 2008; Igual et al., 2011; Ihns et al., 2011; Suna et al., 2014).

The apricot (Prunus armeniaca L.) fruit is considered as one of the most delicious temperate fruits and consumed because of its delicate flavor and high nutritional quality (Elmac1 et al., 2008). Turkey, Spain, Italy, France and Greece are the greatest apricot-producing countries in the world. According to the Food and Agriculture Organization of the United Nations Statistical Database (Food and Agriculture Organization of the United Nations, 2012), 795768 million tons of apricots were produced in Turkey, making it the first country in the production ranking list, contributing to $20.11 \%$ of the total production in the world.

Apricots are rich in carbohydrates and minerals, having a striking color and characteristic flavor (Ghorpade et al., 1995). Sugars such as glucose, fructose, sucrose, and sorbitol and malic and citric acid are the main components. The most abundant minerals are potassium and iron. The apricot fruit is an important source of provitamin A carotenoids, as $250 \mathrm{~g}$ of fresh or $30 \mathrm{~g}$ of dried fruit supplies $100 \%$ of the RDA (recommended dietary allowance) of carotenoids. $\beta$-carotene comprises $60-70 \%$ of total carotenoids in apricots. Additionally, chlorogenic and neochlorogenic acids, (+)-catechin, (-)-epicatechin and rutin (or quercetin-3-rutinoside) are the most important phenolic compounds in this fruit (Drogoudi et al., 2008).

To increase the shelf life of foods, drying is the oldest process (Cakmak \& Yildız, 2011). Dried fruits and vegetables have been considered as an alternative fat-free snack and have gained much more attention recently (Devahastin \& Niamnuy, 2010). Due to its benefits to human health, there is an increasing demand for dried apricots worldwide. Moreover, there is a remarkable interest in polyphenols and carotenoids in this fruit due to their antioxidant activity and ability to prevent chronic diseases (Rice-Evans et al., 1997; Gardner et al., 2000).

To preserve the nutritional and sensorial quality of fresh apricots, choosing the best drying technique and optimization of the drying conditions is very significant (Sablan1, 2006; Karatas \& Kamisl1, 2007). The commonly used technique of drying apricots is sun drying, which requires little capital, basic equipment and low energy input (Abdelhaq \& Labuza, 1987). However, the most preferred way to conserve food by reducing its moisture content is convective drying (Mundada et al., 2010). Nevertheless the drying of fruit over a long time at high temperatures is the biggest disadvantage of conventional hot-air drying. The exposure of apricots to high temperatures 
for a long time in the presence of oxygen induces enzymatic and non-enzymatic oxidation. These conditions lead to some changes in not only the sensorial attributes of the product, such as color and flavor, but also the content and profile of carotenoids (Zhang et al., 2006; Rodriguez-Amaya, 2010).

Microwave drying is an alternative method with several advantages, such as uniform energy delivery, high thermal conductivity to the interior of the food, better space utilization, sanitation, energy costs, precise process control and rapid start-up and shutdown conditions (Maskan, 2000). Microwave heating considerably lowers transient thermal time until the required temperature is reached, thus shortening drying time compared to convective heating (Fratianni et al., 2013). García-Martínez et al. (2013) reported that when compared to hot air drying, the use of microwaves reduced the drying time by $82 \%$. On the other hand, this type of drying has some disadvantages, such as non-uniform heating, possible textural damage, high investment costs and the limited penetration of microwave radiation (Zhang et al., 2006). A comparison between convective and microwave-based systems was previously conducted for the drying of apples and apricots at different temperatures with an on-line temperature control (Cuccurullo et al., 2012; Albanese et al., 2013). To reduce the drying problems mentioned above, microwave drying has been combined with existing drying techniques, which include convective air drying (cabinet, fluidized bed and tunnel), spray, vacuum, a foam mat and freeze-drying (Prabhanjan et al., 1995).

There is limited data on alternative methods of drying apricot cubes and their effect on a color, antioxidant activity, $\beta$-carotene and minerals. Some recent studies on microwave-convective drying include the drying of carrots (Prabhanjan et al., 1995), cranberries (Sunjka et al., 2004) and spinach (Karaaslan \& Tuncer, 2008). The aim of this study is to select the most suitable drying technique between microwave, convective and microwaveconvective drying and to determine the differences in some physicochemical properties between fresh and dried apricots.

\section{Materials and methods}

\subsection{Materials}

Apricots were harvested in an orchard in Malatya province, Turkey and stored at $\pm 4{ }^{\circ} \mathrm{C}$. Prior to the drying process, apricots were taken out of storage and cut into approximately 3-4 $\mathrm{mm}^{3}$ cubes. The pieces were placed into the oven above a perforated pan $\left(210 \mathrm{~mm}^{3} \times 450 \mathrm{~mm}^{3} \times 420 \mathrm{~mm}^{3}\right.$ internal sizes of oven), and drying was started by the manual setting of a machine to the desired conditions.

\subsection{Drying conditions}

The drying treatment was performed in a laboratory microwave-convective oven (Whirlpool AMW 545, Comerio, Italy), with technical features of $\sim 230 \mathrm{~V}, 50 \mathrm{~Hz}$ and a frequency of $2450 \mathrm{MHz}$. The drying experiments were conducted using three different drying techniques: microwave, convective and microwave-convective drying. The system was set in convective mode in an air velocity of $1 \mathrm{~m} \mathrm{~s}^{-1}$ with air temperatures of $50{ }^{\circ} \mathrm{C}$ and $75{ }^{\circ} \mathrm{C}$; in microwave mode at output power levels of $90 \mathrm{~W}$ and $160 \mathrm{~W}$; and in microwave-convective mode at four different combinations of power level and temperature $\left(50{ }^{\circ} \mathrm{C}+90\right.$ watt, $50{ }^{\circ} \mathrm{C}+160$ watt, $75^{\circ} \mathrm{C}+90$ watt, $75^{\circ} \mathrm{C}+160$ watt). The microwave, convective and combined microwave-convective drying experiments were carried out in an area consisting of a rotating glass plate with a $400 \mathrm{~mm}$ diameter at the base of the oven. $200 \mathrm{~g}$ of apricot cubes were placed on a glass plate in a thin layer and drying was started. For mass determination, a digital balance (Baster, Istanbul, Turkey) with $0.01 \mathrm{~g}$ precision was placed under the oven (Giri \& Prasad, 2007). Three replicates were performed for each sample, and the mean value was calculated.

\subsection{Physicochemical analysis}

Total dry matter content, antioxidant activity, $\beta$-carotene, minerals $(\mathrm{K}, \mathrm{Ca}, \mathrm{Mg}, \mathrm{Zn})$, and surface color $\left(L^{*}, a^{*}, b^{*}, \Delta E_{\mathrm{ab}}\right.$, $\mathrm{h}^{\circ}, \mathrm{C}_{\mathrm{ab}}^{*}$ ) analyses were conducted for the dried apricot samples. The total dry matter content of samples was determined by using the oven drying method (Cemeroğlu, 2007). The procedure carried out to determine antioxidant activity in the apricot and dried apricot samples was based on the inhibition of the free radical 2,2-diphenyl-1-picrilhydrazil (DPPH) in methanol extracts of the samples. The DPPH radical has an intense violet color that becomes colorless as unpaired electrons are sequestered by antioxidants. In this method, extracted samples, which were made to react with the radical solution and rest for $30 \mathrm{~min}$ at room temperature, were measured for absorbance at $517 \mathrm{~nm}$, and the inhibition percentage of DPPH free radical was calculated (Zhang \& Hamauzu, 2004). The extracts for antioxidant activity were tested at a concentration of $8 \mathrm{mg} / \mathrm{mL}$ based on dry matter. Antioxidant activity values were analyzed based on dry matter to compare the raw material and dried samples with different dry matter contents. The radical scavenging activity was expressed as \% of inhibition according to Equation 1 (William et al., 1995; Lin et al., 2005).

DPPH Radical Scavenging Activity $(\%)=\left[\left(A_{\text {control }}-A_{\text {sample }}\right) / A_{\text {control }}\right] * 100$

where $\mathrm{A}_{\text {control }}$ and $\mathrm{A}_{\text {sample }}$ are the absorbances of the control and sample, respectively.

The HPLC method was employed to determine $\beta$-carotene using Agilent 1100 series high-performance liquid chromatography. The homogenized sample of fresh or dried apricots $(10 \mathrm{~g})$ was mixed with a methanol/Tetrahydrofuran (THF) (1:1) extraction solution in a $100 \mathrm{~mL}$ volumetric flask. The well-shaken extract was filtered and then filtered through a $0.45 \mathrm{~mm}$ membrane filter again; then, $20 \mathrm{~mL}$ was injected into the HPLC column. Separations were achieved on a C18 column with a flow rate of $0.8 \mathrm{~mL} / \mathrm{min}$. The UV spectrum of $\beta$-carotene was recorded using a diode array detector. The mobile phase consisted of $95 \%$ methanol with 5\% THF (HPLC grade). The Agilent 1100 HPLC system, integrated with an auto sampler including temperature control for the column and a personal computer with a software package for system control and data acquisition, was used for analyses. $\beta$-carotene concentrations were calculated by comparing their "peak area" values at $450 \mathrm{~nm}$ with stock standard solutions and expressed as milligrams per 100 grams of dry matter by using the Equation 2 (Konings \& Roomans, 1997).

$E=(F / B) x Z x S$ 
$\mathrm{E}=$ Amount of $ß$-carotene in the sample $(\mathrm{mg} / 100 \mathrm{~g})$.

$\mathrm{F}=$ Peak area of the sample.

$\mathrm{B}=$ Peak area of the standard.

$\mathrm{Z}=$ Concentration of the standard (mg/100 g).

$\mathrm{S}=$ Dilution coefficient.

For analysis of the mineral content, the NMKL (Nordic Committee on Food Analysis, 2007) method was employed, and Agilent 7500 CX (Agilent Technologies, Santa Clara, CA, USA) model ICP-MS was used. According to this method, $0.5 \mathrm{~g}$ of homogenized sample, $4 \mathrm{~mL}$ of $\mathrm{HNO}_{3}(65 \%)$ and $1 \mathrm{~mL}$ of $\mathrm{H}_{2} \mathrm{O}_{2}(35 \%)$ were incinerated in a microwave digestion system (Berghof mws3). The digested sample was transferred to a $50 \mathrm{~mL}$ volumetric flask and diluted with distilled water. To determine the color values, the Hunter colorimetric system was applied by using a Miniscan EZ4500L model HunterLab colorimeter. The measurements were displayed in $L^{*}$ : lightness, $a^{*}$ : redness, $b^{*}$ : yellowness. The surface color of samples was measured on different parts and expressed as the mean of three replicate readings. Total color difference $\left(\Delta E_{\mathrm{ab}}{ }^{*}\right)$, chroma $\left(\mathrm{C}^{*}{ }_{\mathrm{ab}}\right)$ and hue angle $\left(\mathrm{h}^{\circ}\right)$ values were also calculated from the $L^{\star}, a^{\star}, b^{\star}$ values (Özkan et al., 2003; Berasategi et al., 2014).

CIE color notation locates a color in a three-dimensional space defined by lightness $\left(L^{*}\right)$ and the chromaticity coordinates $a^{\star}$ and $b^{\star} . L^{\star}$ is scaled from 0 (black) to 100 (white). Positive $a^{*}$ indicates red direction and is scaled from 0 (achromatic) to 60 (red). Positive $b^{\star}$ indicates yellow direction and is scaled from 0 (achromatic) to 60 (yellow). $C^{\star}$, chroma, changes from 0 (dull) to 60 (vivid) and was calculated from the $a^{\star}$ and $b^{\star}$ values by using the Equation 3:

$C^{*}=\left(a^{2}+b^{2}\right)^{1 / 2}$

Hue angle, $\mathrm{h}^{*}$, is the color value and is defined as starting at the $+\mathrm{a}^{\star}$ axis. It is expressed in degrees: $0^{\circ}$ (red), $90^{\circ}$ (yellow), $180^{\circ}$ (green) and $270^{\circ}$ (blue). $\mathrm{h}^{\circ}$ was also calculated from the $a^{\star}$ and $b^{\star}$ values by using the Equation 4 :

$h^{\circ}=\arctan \left(b^{*} / a^{*}\right)$

$\Delta \mathrm{Eab}^{*}$ is based on the $L^{*}, a^{*}, b^{*}$ color difference and was intended to be a single number metric for pass/fall decision and calculated by using Equation 5 (Grad et al., 2011).

$$
\Delta E a b^{*}=\sqrt{\Delta \boldsymbol{L}^{2}+\Delta \boldsymbol{a}^{2}+\Delta \boldsymbol{b}^{2}}
$$

Triplicate measurements were performed for all physicochemical properties in each batch of apricot samples.

\subsection{Statistical analysis}

The experiment was conducted in a completely randomized design with three replications. The results were statistically evaluated via one-way analysis of variance (ANOVA) using the JMP software package version 6.0 (SAS Institute, 2005). When significant differences were determined $(p<0.01)$, the
Least Significant Difference (LSD) test was used to determine the differences among means.

\section{Results and discussion}

The analysis results of raw material (Table 1 ) and dried fruits (Table 2 and Table 3 ) are shown in the tables below.

Mean values of total dry matters were similar to those reported by Akın et al. (2008) (11.83-25.81\%), who determined the composition of apricot varieties from the Malatya region of Turkey. Ali et al. (2011) also reported the dry matter composition (14.70-21.20\%) of six apricot varieties grown in northern areas of Pakistan, and Karabulut et al. (2007) determined the dry matter of fresh Hacihaliloglu apricots (22.3\%), which was closer to our results. The results of Madrau et al. (2009), determined for Pelese (16.09\%) and Cafona (15.71\%) apricot cultivars, were lower than the results determined in this study.

Apricot fruits are regarded as a rich source of carotenoids, especially $\beta$-carotene, which represents more than $50 \%$ of the total carotenoid content (Radi et al., 1997; Sass-Kiss et al., 2005; Sağırlı et al., 2008). In addition to $\beta$-carotene, apricot fruit and its products contain smaller amounts of $\alpha$-carotene, $\gamma$-carotene, zeaxantin and lutein (Fraser \& Bramley, 2004). Akın et al. (2008) and Karabulut et al. (2007) reported the $\beta$-carotene values as $5.74-48.69 \mathrm{mg} / 100 \mathrm{~g}$ dry weight in Malatya apricots and $9.84 \mathrm{mg} / 100 \mathrm{~g}$ dry weight in the Hacihaliloglu apricot variety. Dragovic-Uzelac et al. (2007) determined the $\beta$-carotene contents of three apricot cultivars of two geographical region of Croatia to be between 585.4-1374.95 $\mu \mathrm{g} / 100 \mathrm{~g}$. Campbell et al. (2013) reported the same content of five apricot varieties to be between $7174.5-1041.7 \mu \mathrm{g} / 100 \mathrm{~g}$ in commercial ripe, tree ripe and storage stages. The differences could be due to the carotenoid content being dependent on genetic, environmental and agronomic features (Rodriguez-Amaya, 2010).

The antioxidant activity of apricots was found to be $46.52 \%$, as seen in Table 1. While the DPPH inhibition ratio of apricots in our study (46.52\%) was comparable with the results reported by Hegedus et al. (2010) in different cultivars (6.43-74.45\%), the

Table 1. Results of the physicochemical analysis of the apricot fruit.

\begin{tabular}{lc}
\hline \multicolumn{1}{c}{ Analysis } & Mean \\
\hline Total dry matter $(\mathrm{g} / 100 \mathrm{~g})$ & $21.39 \pm 0.10$ \\
Antioxidant activity (\%) & $46.52 \pm 0.10$ \\
$\beta$-carotene $(\mathrm{mg} / 100 \mathrm{~g})$ & $19.09 \pm 0.08$ \\
Minerals (mg/kg) & \\
$\mathrm{K}$ & $3849 \pm 114.55$ \\
$\mathrm{Ca}$ & $245 \pm 12.73$ \\
$\mathrm{Mg}$ & $101 \pm 3.53$ \\
$\mathrm{Zn}$ & $0.27 \pm 0.00$ \\
$\mathrm{Color}$ & \\
$L^{*}$ & $65.77 \pm 0.18$ \\
$a^{*}$ & $21.97 \pm 0.34$ \\
$b^{*}$ & $49.90 \pm 1.74$ \\
$\Delta E_{\mathrm{ab}}{ }^{*}$ & $85.14 \pm 0.95$ \\
$\mathrm{~h}^{\circ}$ & $66.14 \pm 0.36$ \\
$\mathrm{C}^{*}$ & $54.15 \pm 1.46$ \\
\hline
\end{tabular}


Table 2. Results of the physicochemical analysis of dried apricot samples.

\begin{tabular}{|c|c|c|c|c|c|c|c|}
\hline Drying Conditions & $\begin{array}{c}\text { Total dry } \\
\text { matter }(\mathrm{g} / 100 \mathrm{~g})\end{array}$ & $\begin{array}{l}\text { Antioxidant } \\
\text { activity (\%) }\end{array}$ & $\begin{array}{l}\beta \text {-carotene } \\
(\mathrm{mg} / 100 \mathrm{~g})\end{array}$ & $\begin{array}{c}\mathrm{K} \\
(\mathrm{mg} / \mathrm{kg})\end{array}$ & $\begin{array}{c}\mathrm{Ca} \\
(\mathrm{mg} / \mathrm{kg})\end{array}$ & $\begin{array}{c}\mathrm{Mg} \\
(\mathrm{mg} / \mathrm{kg})\end{array}$ & $\begin{array}{c}\mathrm{Zn} \\
(\mathrm{mg} / \mathrm{kg})\end{array}$ \\
\hline $\mathrm{A}\left(50^{\circ} \mathrm{C}\right)$ & $76.43 \pm 0.54 \mathrm{e}$ & $56.72 \pm 0.60 \mathrm{a}$ & $83.44 \pm 0.90 c$ & $18566.60 \pm 58.72 b$ & $1724.51 \pm 0.50 \mathrm{~b}$ & $414.89 \pm 1.67 b$ & $6.55 \pm 0.03 b$ \\
\hline $\mathrm{B}\left(75^{\circ} \mathrm{C}\right)$ & $85.52 \pm 2.52 \mathrm{a}$ & $67.12 \pm 2.34 b$ & $50.41 \pm 0.46 f$ & $21284.37 \pm 1509.79 a$ & $2947.69 \pm 156.11 \mathrm{a}$ & $543.45 \pm 41.62 \mathrm{a}$ & $3.67 \pm 0.13 \mathrm{~d}$ \\
\hline C (90 watt) & $78.35 \pm 0.04 \mathrm{~d}$ & $59.51 \pm 1.10 c$ & $68.83 \pm 0.33 \mathrm{~d}$ & $15516.53 \pm 107.70 c$ & $466.27 \pm 35.84 \mathrm{e}$ & $425.55 \pm 29.66 b$ & $5.01 \pm 0.51 \mathrm{c}$ \\
\hline D (160 watt) & $82.24 \pm 0.34 b$ & $82.83 \pm 0.31 \mathrm{~d}$ & $45.96 \pm 0.47 \mathrm{~h}$ & $17035.51 \pm 37.17 b c$ & $907.11 \pm 30.22 \mathrm{~d}$ & $502.74 \pm 6.08 \mathrm{a}$ & $7.96 \pm 0.54 \mathrm{a}$ \\
\hline $\mathrm{E}\left(50^{\circ} \mathrm{C}+90\right.$ watt $)$ & $80.53 \pm 0.68 c$ & $64.27 \pm 1.67 \mathrm{e}$ & $93.29 \pm 0.58 \mathrm{a}$ & $15356.03 \pm 1458 c$ & $775.84 \pm 68.06 \mathrm{~d}$ & $547.14 \pm 22.52 \mathrm{a}$ & $7.42 \pm 0.68 \mathrm{ab}$ \\
\hline $\mathrm{F}\left(50^{\circ} \mathrm{C}+160\right.$ watt $)$ & $81.91 \pm 2.57 b$ & $69.73 \pm 1.68 \mathrm{f}$ & $88.07 \pm 0.34 b$ & $17641.00 \pm 455.73 b$ & $534.60 \pm 31.55 \mathrm{e}$ & $530.94 \pm 13.25 a$ & $7.29 \pm 0.53 \mathrm{ab}$ \\
\hline $\mathrm{G}\left(75^{\circ} \mathrm{C}+90\right.$ watt $)$ & $82.22 \pm 0.17 b$ & $53.85 \pm 0.15 \mathrm{~g}$ & $63.30 \pm 0.35 \mathrm{e}$ & $478.78 \pm 17.67 \mathrm{~d}$ & $1195.43 \pm 5.28 \mathrm{c}$ & $224.46 \pm 7.97 \mathrm{c}$ & $3.45 \pm 0.03 \mathrm{~d}$ \\
\hline $\mathrm{H}\left(75^{\circ} \mathrm{C}+160\right.$ watt $)$ & $78.70 \pm 0.63 \mathrm{~d}$ & $43.34 \pm 1.78 \mathrm{~h}$ & $48.01 \pm 0.22 h$ & $456.53 \pm 11.23 \mathrm{~d}$ & $839.96 \pm 4.61 d$ & $195.94 \pm 11.17 \mathrm{c}$ & $7.25 \pm 0.57 \mathrm{ab}$ \\
\hline
\end{tabular}

Different letters in the same column indicate significant difference $(\mathrm{p}<0.01)$.

Table 3. Color values of dried apricot samples.

\begin{tabular}{|c|c|c|c|c|c|c|}
\hline Drying Conditions & $L^{*}$ & $a^{*}$ & $b^{*}$ & $\Delta \mathrm{E}_{a b}^{*}$ & $\mathbf{h}^{\circ}$ & $C_{a b}^{*}$ \\
\hline $\mathrm{A}\left(50^{\circ} \mathrm{C}\right)$ & $45.64 \pm 0.14$ & $23.37 \pm 0.07$ & $40.04 \pm 0.06$ & $65.05 \pm 0.15$ & $59.76 \pm 0.07$ & $46.36 \pm 0.08$ \\
\hline $\mathrm{B}\left(75^{\circ} \mathrm{C}\right)$ & $46.57 \pm 0.07$ & $21.60 \pm 0.10$ & $46.76 \pm 0.16$ & $69.43 \pm 0.18$ & $65.21 \pm 0.05$ & $51.51 \pm 0.19$ \\
\hline C (90 watt) & $44.42 \pm 0.02$ & $22.54 \pm 0.04$ & $44.74 \pm 0.14$ & $66.95 \pm 0.12$ & $63.26 \pm 0.05$ & $50.09 \pm 0.14$ \\
\hline$D$ (160 watt) & $40.18 \pm 0.08$ & $23.08 \pm 0.08$ & $39.79 \pm 0.09$ & $61.07 \pm 0.14$ & $59.90 \pm 0.07$ & $46.00 \pm 0.12$ \\
\hline $\mathrm{E}\left(50^{\circ} \mathrm{C}+90\right.$ watt $)$ & $45.08 \pm 0.08$ & $26.35 \pm 0.05$ & $44.66 \pm 0.16$ & $68.70 \pm 0.17$ & $59.46 \pm 0.07$ & $51.85 \pm 0.16$ \\
\hline $\mathrm{F}\left(50^{\circ} \mathrm{C}+160\right.$ watt $)$ & $39.14 \pm 0.06$ & $22.34 \pm 0.09$ & $41.44 \pm 0.04$ & $61.22 \pm 0.02$ & $61.68 \pm 0.07$ & $47.08 \pm 0.08$ \\
\hline $\mathrm{G}\left(75^{\circ} \mathrm{C}+90\right.$ watt $)$ & $40.55 \pm 0.05$ & $23.14 \pm 0.06$ & $42.72 \pm 0.12$ & $63.28 \pm 0.10$ & $61.61 \pm 0.13$ & $48.58 \pm 0.08$ \\
\hline $\mathrm{H}\left(75^{\circ} \mathrm{C}+160\right.$ watt $)$ & $36.27 \pm 0.07$ & $23.06 \pm 0.04$ & $35.40 \pm 0.10$ & $55.68 \pm 0.09$ & $56.92 \pm 0.09$ & $42.24 \pm 0.06$ \\
\hline
\end{tabular}

same ratio was higher than the result of Rababah et al. (2011) (29.20\%). Ali et al. (2011) determined the DPPH free radical scavenging activity of six apricot varieties grown in northern areas of Pakistan to be 55.70-82.33\%. Discrepancies between data in the present study and those of the other studies could be related to a wide variety of factors, such as the cultivar, environmental and storage conditions of the apricots.

$\mathrm{K}, \mathrm{Ca}$, and $\mathrm{Mg}$ are considered major minerals of the apricot fruit (Drogoudi et al., 2008). The mineral content of the USDA National Nutrient Database for apricots is $259 \mathrm{mg} / 100 \mathrm{~g}$ for K, $10 \mathrm{mg} / 100 \mathrm{~g}$ for $\mathrm{Mg}, 13 \mathrm{mg} / 100 \mathrm{~g}$ for $\mathrm{Ca}$ and $0.20 \mathrm{mg} / 100 \mathrm{~g}$ for Zn (United States Department of Agriculture Agricultural Research Service, 2014). Akın et al. (2008) determined the K, Mg, $\mathrm{Ca}$ and $\mathrm{Zn}$ contents of eleven apricot varieties similar to ours as $1227-3455$ mg/100 g, 110.4-284.4 mg/100 g, 87-240.5 mg/100 g and $1.38-4.24 \mathrm{mg} / 100 \mathrm{~g}$ based on dry matter, respectively. The data pertaining to mineral contents $(\mathrm{mg} / 100 \mathrm{~g})$ revealed $\mathrm{K}$ as the predominant element (2040-3000), followed by $\mathrm{P}, \mathrm{Mg}, \mathrm{Ca}, \mathrm{Na}$ and $\mathrm{Fe}$, among all the tested samples in the research of Ali et al. (2011). According to many studies, the composition of the fruits was affected by climate, variety, geographical origin, harvest year and the methods of cultivation (Açkurt et al., 1999). In as much as apricots can be regarded as a good source of minerals, the consumption of 3-4 fresh apricots per day may supply the daily requirement of $\mathrm{K}, \mathrm{Mg}, \mathrm{Fe}, \mathrm{Se}$, and $\mathrm{Mn}$ and half of $\mathrm{P}$ and $\mathrm{Zn}$ for an average adult (Akın et al., 2008).

The color indices $\mathrm{h}^{\circ}, L^{*}$, and $\mathrm{C}^{*}{ }_{\mathrm{ab}}$ are widely used for objective color description (Ruiz et al., 2005). In general, the decrease in $L *$ and $h^{\circ}$ reflects the darkening of apricot flesh and a shift from white to orange, respectively. Ruiz et al. (2005) reported that hue angle $\left(h^{\circ}\right)$ is a suitable parameter for estimating the carotenoid content of apricots.

Color values coincided with results reported by Ihns et al. (2011) and Akın et al. (2008). The first researchers determined the average $L^{*}, a^{*}$ and $b^{*}$ color values of two different apricot varieties as being between 52.1-56.9, 24.3-26.7 and 44.5-50.1, respectively. The latter measured the same parameters as being between 52.5-62.2, 10.7-21.1 and 20.4-28.9, respectively. Closer to our results, Hegedus et al. (2010) reported hue angle values of $62.63-84.63, L *$ values of $60.15-72.43$ and chroma values of 51.66-68.48 in the fruit flesh of selected apricot cultivars and hybrids. Particularly, $L^{*}$ values were similar to the results of Karabulut et al. (70.7) and Akın et al. (2008). According to the results of Campbell et al. (2013) and Melgarejo et al. (2014), while $L^{*}$ and $a^{*}$ values were found to be higher, $b^{*}$ values were found to be similar to those in this study. Additionally, all color values determined by Coşkun et al. (2013) in the Hacıhaliloğlu variety apricots were lower than ours. Similar ho values in the research of Coşkun et al. (2013) might show a similarity in carotenoid contents of both apricot varieties. Good correlations have been found between the Hunter $b^{*}$ value and $\beta$-carotene concentration in sweet potatoes (Ameny \& Wilson, 1997); the Hunter $a^{*}$ value and carotenoid concentration in paprika (Ramakrishnan \& Francis, 1973); the Hunter $a^{*}$ and $\mathrm{h}^{\circ}$ values and carotenoid concentration in orange juice (Gullett et al., 1972).

The moisture contents of the dried apricot samples were found to be significantly different, between $76.43 \pm 0.54-85.52 \pm 2.52 \mathrm{~g} / 100 \mathrm{~g}$ $(\mathrm{p}<0.01$, Table 2). According to the Codex Standard for dried apricots (Codex Alimentarius, 1981), the moisture content should not exceed $20 \%$ when unsulfured samples are not treated with sorbic acid. The final moisture contents of dried apricots 
were designated according to literature data, pre-treatments and organoleptic properties. Igual et al. (2011) reported the moisture content of dried apricots as being between $20-25 \mathrm{~g} / 100 \mathrm{~g}$ when applied in commercial applications. Similarly, Özkan et al. (2003) and Karabulut et al. (2007) determined the moisture contents as being $15.49-30.20 \%$ and $25 \%$ in dried apricots, respectively. Madrau et al. (2009) dried apricots at two different temperatures $\left(55^{\circ} \mathrm{C}\right.$ and $\left.75^{\circ} \mathrm{C}\right)$ to $79.84-80.85 \%$ dry matter, and then investigated the antioxidant activity and phenolic contents of the samples. In another study, Coşkun et al. (2013) reported 15.41-19.01\% moisture for the dried Kabaaşı variety of apricots and $21.27-22.58 \%$ for the Hacihaliloğlu variety. All dry matter contents previously determined were similar to our results.

Generally, the inhibition of DPPH radicals significantly increased for dried apricots, ranging from 43.34 to $82.83 \%$ (Table 2) compared with fresh samples $(\mathrm{p}<0.01)$. This increase may be explained by several factors, such as the increased antioxidant power of polyphenols at an intermediate state of oxidation, increase in reducing sugar and formation of Maillard reaction products, known to have a great antioxidant activity, which is often exerted in a chain-breaking and DPPH type mechanism (Nicoli et al., 1999; Del Caro et al., 2004; Manzocco et al., 2001; Morales \& Jiménez-Pérez, 2004). Igual et al. (2011) and Madrau et al. (2009) similarly determined increased antioxidant activity values in dried apricots. Higher temperature and power level treatments $(\mathrm{G}, \mathrm{H})$ caused less inhibition of DPPH radical. This could be due to the degradation of antioxidative compounds, such as carotenoids and ascorbic acid (Penicaud et al., 2011; Albanese et al., 2013).

$\beta$-carotene is responsible for the specific color of apricot varieties. The evolution of $\beta$-carotene contents, for both heating methods and temperatures investigated, showed different behaviors (Table 2). Drying at 160 watt (D) caused more carotene loss when compared to convective drying and other modes for both temperatures tested $(\mathrm{p}<0.01)$. Elevated conditions (temperatures and power levels) provided a decrease in $\beta$-carotene content of the samples. As seen from the table, $50^{\circ} \mathrm{C}(\mathrm{A})$ and its combined conditions (E, F) showed the highest $\beta$-carotene values after drying. Regardless, $\beta$-carotene is prone to degradation, and more precisely, to isomerization, especially at high temperatures and oxidation (Karabulut et al., 2007; Penicaud et al., 2011). Coşkun et al. (2013) determined the $\beta$-carotene contents of sulfured apricots to be between $26.4-30.8 \mathrm{mg} / 100 \mathrm{~g}$ for the Kabaaşı cultivar and 30.0-33.3 mg/100 g for the Hacıhaliloğlu cultivar and investigated the effect of storage temperatures on this component. Results that are less pronounced than ours could be due to variety, treatment differences and other factors. Microwave drying caused a higher decrease in carotene compounds compared with the singly convective method. Taking all these considerations into account, the industrial processing of dried apricots may be improved by using microwave energy with convective drying because the drying time is substantially reduced and the dried fruit has a higher phenolic content and a good color (Igual et al., 2011).

The mineral contents of dried apricots were found to be statistically significant $(\mathrm{p}<0.01)$. On the other hand, they showed an order similar to the raw material in terms of $\mathrm{K}, \mathrm{Ca}, \mathrm{Mg}$ and $\mathrm{Zn}$ minerals. Due to the relative dry matter increment during drying treatment, the dried samples had the highest mineral contents per kg compared with the fresh samples.

Many researchers have shown the $L^{\star}$ value to be a measure of browning index in fruits and fruit products. A decrease in $L^{*}$ value correlated well with an increase in brown pigment concentration in paprika (Ramakrishnan \& Francis, 1973), raisins (Aguilera et al., 1987), pineapple concentrates (Fontana et al., 1993), grape fruit juices (Lee \& Nagy, 1988), apple slices (Beveridge \& Weintraub, 1995) and concentrated apple, peach and plum pulps (Lozano \& Ibarz, 1997). This darkening was explained by carotenoid accumulation (Ruiz et al., 2005). 160-watt application for drying was unsuitable in terms of color darkening of the product. All $L^{\star}$ values were lower in these samples $(\mathrm{D}, \mathrm{F}$ and $\mathrm{H})$ (Table 3). Özkan (2001) reported that the $L^{\star}$ (4.7 units), $b^{*}$ (2.9 units), $\mathrm{C}_{a b}^{*}\left(2.7\right.$ units) and $\mathrm{h}^{\circ}$ (2.8 units) color values were increased, while the $a^{*}$ (0.7 unit) value decreased, in dried apricots exposed to $40^{\circ} \mathrm{C}$ for 13 days, compared to initial color values. As the moisture content increased, the $L^{\star}, b^{*}, \mathrm{C}^{*}{ }_{a b}$ and $\mathrm{h}^{\circ}$ color values increased, while the $a^{*}$ value decreased, for the dried apricots at all moisture levels (Özkan et al., 2003). Some discrepancies could be due to the moisture level of the dried samples or differences in process conditions.

\section{Conclusion}

The drying of apricots via both microwave and hot air treatment caused undesirable color browning. These color-related reactions were sometimes caused by the presence of new components with high antioxidant activity. Thus, all antioxidant activity values were found to be higher than in fresh fruit. In addition to antioxidant activity, other components, such as $\beta$-carotene and minerals, were increased by the increase of dry matters. Particularly, low temperature with low power level $\left(\mathrm{E}-50^{\circ} \mathrm{C}+90\right.$ watt $)$ provided the highest $\beta$-carotene level of the products. As a consequence, the industrial drying process of apricots may be progressed by using microwave-convective drying techniques because the drying time is considerably reduced and the obtained fruit has a higher $\beta$-carotene content, while antioxidant activity is maintained.

\section{Acknowledgements}

This work was edited for proper English language, grammar, punctuation, spelling, and overall style by native English speaking editors at American Journal Experts (AJE).

\section{References}

Abdelhaq, E. H., \& Labuza, T. P. (1987). Air drying characteristics of apricots. Journal of Food Science, 52(2), 342-345. http://dx.doi. org/10.1111/j.1365-2621.1987.tb06608.x.

Açkurt, F., Ozdemir, M., Biringen, G., \& Löker, M. (1999). Effects of geographical origin and variety on vitamin and mineral composition of hazelnut (Corylus avellana L.) varieties cultivated in Turkey. Food Chemistry, 65(3), 309-313. http://dx.doi.org/10.1016/S03088146(98)00201-5.

Aguilera, J. M., Oppermann, K., \& Sanchez, F. (1987). Kinetics of browning of sultana grapes. Journal of Food Science, 52(4), 990-993. http://dx.doi.org/10.1111/j.1365-2621.1987.tb14258.x. 
Akın, E. B., Karabulut, I., \& Topcu, A. (2008). Some compositional properties of main Malatya apricot (Prunus armeniaca L.) varieties. Food Chemistry, 107(2), 939-948. http://dx.doi.org/10.1016/j. foodchem.2007.08.052.

Albanese, D., Cinquanta, L., Cuccurullo, G., \& Di Matteo, M. (2013). Effects of microwave and hot air and drying methods on color, $\beta$-carotene and radical scavenging activity of apricots. International Journal of Food Science, 48(6), 1327-1333. http://dx.doi.org/10.1111/ ijfs. 12095.

Ali, S., Masud, T., \& Abbasi, K. S. (2011). Physico-chemical characteristics of apricot (Prunus armeniaca L.) grown in Northern Areas of Pakistan. Scientia Horticulturae, 130(2), 386-392. http://dx.doi.org/10.1016/j. scienta.2011.05.040.

Ameny, M. A., \& Wilson, P. W. (1997). Relationship between Hunter Color Values and $\beta$-Carotene Contents in White-Fleshed African Sweet potatoes (Ipomoea batatas Lam.). Journal of the Science of Food and Agriculture, 73(3), 301-306. http://dx.doi.org/10.1002/ (SICI)1097-0010(199703)73:3<301::AID-JSFA726>3.0.CO;2-Z.

Berasategi, I., Navarro-Blasco, Í., Calvo, M. I., Cavero, R. Y., Astiasarán, I., \& Ansorena, D. (2014). Healthy reduced-fat Bologna sausages enriched in ALA and DHA and stabilized with Melissa officinalis extract. Meat Science, 96(3), 1185-1190. http://dx.doi.org/10.1016/j. meatsci.2013.10.023. PMid:24334039.

Beveridge, T., \& Weintraub, S. E. (1995). Effect of blanching pretreatment on color and texture of apple slices at various water activities. Food Research International, 28(1), 83-86. http://dx.doi.org/10.1016/09639969(95)93335-R.

Cakmak, G., \& Yild1z, C. (2011). The prediction of seedy grape drying rate using a neural network method. Computers and Electronics in Agriculture, 75(1), 132-138. http://dx.doi.org/10.1016/j. compag.2010.10.008.

Campbell, O. E., Merwin, I. A., \& Padilla-Zakour, O. I. (2013). Characterization and the Effect of Maturity at Harvest on the Phenolic and Carotenoid Content of Northeast USA Apricot (Prunus armeniaca) Varieties. Journal of Agricultural and Food Chemistry, 61(51), 12700-12710. http://dx.doi.org/10.1021/jf403644r. PMid:24328399.

Cemeroğlu, B. S. (2007). Gıda Analizleri (Gıda Teknolojisi Derneği Yayınları, No. 34). Ankara: Bizim Büro Basımevi. 535 p. In Turkish.

Codex Alimentarius, International Food Standards. (1981). Codex Stan 130-1981: standard for dried apricots (pp. 1-5). Retrieved from http:// www.codexalimentarius.org/standards/list-of-standards/

Coşkun, A. L., Türkyılmaz, M., Aksu, Ö. T., Koç, B. E., Yemiş, O., \& Özkan, M. (2013). Effects of various sulphuring methods and storage temperatures on the physical and chemical quality of dried apricots. Food Chemistry, 141(4), 3670-3680. http://dx.doi.org/10.1016/j. foodchem.2013.06.033. PMid:23993535.

Cuccurullo, G., Giordano, L., Albanese, D., Cinquanta, L., \& Di Matteo, M. (2012). Infrared thermography assisted control for apples microwave drying. Journal of Food Engineering, 112(4), 319-325. http://dx.doi.org/10.1016/j.jfoodeng.2012.05.003.

Del Caro, A., Piga, A., Pinna, I., Fenu, P. M., \& Agabbio, M. (2004). Effect of drying conditions and storage period on polyphenolic content, antioxidant capacity and ascorbic acid of prunes. Journal of Agricultural and Food Chemistry, 52(15), 4780-4784. http://dx.doi. org/10.1021/jf049889j. PMid:15264914.

Devahastin, S., \& Niamnuy, C. (2010). Modelling quality changes of fruits and vegetables during drying: a review. International Journal of Food Science \& Technology, 45(9), 1755-1767. http://dx.doi. org/10.1111/j.1365-2621.2010.02352.x.
Dragovic-Uzelac, V. B., Levaj, B. V., Mrkic, D., Bursać, D., \& Boras, M. (2007). The content of polyphenols and carotenoids in three apricot cultivars depending on stage of maturity and geographical region. Food Chemistry, 102(3), 966-975. http://dx.doi.org/10.1016/j. foodchem.2006.04.001.

Drogoudi, P. D., Vemmos, S., Pantelidis, G., Petri, E., Tzoutzoukou, C., \& Karayiannis, I. (2008). Physical characters and antioxidant, sugar, and mineral nutrient contents in fruit from 29 apricot (Prunus armeniaca L.) cultivars and hybrids. Journal of Agricultural and Food Chemistry, 56(22), 10754-10760. http://dx.doi.org/10.1021/ jf801995x. PMid:18975966.

Elmac1, Y., Altug, T., \& Pazir, F. (2008). Quality changes in unsulfured sun dried apricots during storage. International Journal of Food Properties, 11(1), 146-157. http://dx.doi.org/10.1080/10942910701279945.

Fontana, A. J., Howard, I., Criddle, R. S., Hansen, L. D., \& Wilhelmsen, E. (1993). Kinetics of deterioration of pineapple concentrate. Journal of Food Science, 58(6), 1411-1417. http://dx.doi.org/10.1111/j.1365-2621.1993. tb06195.x.

Food and Agriculture Organization of the United Nations - FAO. (2012), FAOSTAT. Rome. Retrieved from http://faostat.fao.org/ site/567/DesktopDefault.aspx?PageID=567\#ancor

Fraser, P. D., \& Bramley, P. M. (2004). The biosynthesis and nutritional uses of carotenoids. Progress in Lipid Research, 43(3), 228-265. http:// dx.doi.org/10.1016/j.plipres.2003.10.002. PMid:15003396.

Fratianni, A., Albanese, D., Mignogna, R., Cinquanta, L., Panfili, G., \& Di Matteo, M. (2013). Degradation of carotenoids in apricot (Prunus armeniaca L.) during drying process. Plant Foods for Human Nutrition, 68(3), 241-246. http://dx.doi.org/10.1007/s11130-0130369-6. PMid:23807280.

García-Martínez, E., Igual, M., Martín-Esparza, M. E., \& MartínezNavarrete, N. (2013). Assessment of the bioactive compounds, color, and mechanical properties of apricots as affected by drying treatment. Food and Bioprocess Technology, 6(11), 3247-3255. http:// dx.doi.org/10.1007/s11947-012-0988-1.

Gardner, P. T., White, T. A., McPhail, D. P., \& Duthie, G. G. (2000). The relative contributions of vitamin $\mathrm{C}$, carotenoids and phenolics to the antioxidant potential of fruit juices. Food Chemistry, 68(4), 471-474. http://dx.doi.org/10.1016/S0308-8146(99)00225-3.

Ghorpade, V. M., Hanna, M. A., \& Kadam, S. S. (1995). Apricot. In D. K. Salunkhe \& S. S. Kadam (Eds.), Handbook of fruit science and technology. New York: Marcel Dekker.

Giri, S. K., \& Prasad, S. (2007). Drying kinetics and rehydration characteristics of microwave-vacuum and convective hot-air dried mushrooms. Journal of Food Engineering, 78(2), 512-521. http:// dx.doi.org/10.1016/j.jfoodeng.2005.10.021.

Grad, M. E., Muntean, S. G., \& Simu, G. M. (2011). Colour expression in the cielab colour scale of new stilbene dyes. In Proceedings of The 17th International Symposium on Analytical and Environmental Problems (pp. 351-354), Szeged, Ungaria.

Gullett, E. A., Francis, F. J., \& Clydesdale, F. M. (1972). Colorimetry of Foods: Orange Juice. Journal of Food Science, 37(3), 389-393. http:// dx.doi.org/10.1111/j.1365-2621.1972.tb02646.x.

Hegedus, A., Engel, R., Abrankó, L., Balogh, E., Blázovics, A., Hermán, R., Halász, J., Ercisli, S., Pedryc, A., \& Stefanovits-Bányai, É. (2010). Antioxidant and antiradical capacities in apricot (Prunus armeniaca L.) fruits: variations from genotypes, years, and analytical methods. Journal of Food Science, 75(9), 722-730. http://dx.doi.org/10.1111/ j.1750-3841.2010.01826.x. PMid:21535583.

Igual, M., García-Martínez, E., Martín-Esparza, M. E., \& MartínezNavarrete, N. (2011). Effect of processing on the drying kinetics and functional value of dried apricot. Food Research International, 91, 1096-1102. 
Ihns, R., Diamante, L. M., Savage, G. P., \& Vanhanen, L. (2011). Effect of temperature on the drying characteristics, color, antioxidant and beta-carotene contents of two apricot varieties. International Journal of Food Science \& Technology, 46(2), 275-283. http://dx.doi. org/10.1111/j.1365-2621.2010.02506.x.

Jiménez, A. M., Martínez-Tomé, M., Egea, I., Romojaro, F., \& Murcia, M. A. (2008). Effect of industrial processing and storage on antioxidant activity of apricot (Prunus armeniaca v. bulida). European Food Research and Technology, 227(1), 125-134. http://dx.doi.org/10.1007/ s00217-007-0701-1.

Karaaslan, S. N., \& Tuncer, I. K. (2008). Development of a drying model for combined microwave-fan-assisted convection drying of spinach. Biosystems Engineering, 100(1), 44-52. http://dx.doi.org/10.1016/j. biosystemseng.2007.12.012.

Karabulut, I., Topcu, A., Duran, A., Turan, S., \& Ozturk, B. (2007) Effect of hot air drying and sun drying on color values and b-carotene content of apricot (Prunus armenica L.). Lebensmittel-Wissenschaft und-Technologie, 40(5), 753-758.

Karatas, F., \& Kamısl, F. (2007). Variations of vitamins (A, C and E) and MDA in apricots dried in IR and microwave. Journal of Food Engineering, 78(2), 662-668. http://dx.doi.org/10.1016/j. jfoodeng.2005.10.040.

Konings, E. J. M., \& Roomans, H. H. S. (1997). Evaluation and validation of an LC method for the analysis of carotenoids in vegetables and fruit. Food Chemistry, 59(4), 599-603.

Lee, H. S., \& Nagy, S. (1988). Quality changes and nonenzymatic browning intermediates in grapefruit juice during storage. Journal of Food Science, 53(1), 168-180. http://dx.doi.org/10.1111/j.1365-2621.1988. tb10201.x.

Lin, Y. T., Vattem, D., Labbe, R. G., \& Shetty, K. (2005). Enhancement of antioxidant activity and inhibition of Helicobacter pylori by phenolic phytochemical-enriched alcoholic beverages. Process Biochemistry, 40(6), 2059-2065. http://dx.doi.org/10.1016/j.procbio.2004.07.019.

Lozano, J. E., \& Ibarz, A. (1997). Color changes in concentrated fruit pulp during heating at high temperatures. Journal of Food Engineering, 31(3), 365-373. http://dx.doi.org/10.1016/S0260-8774(96)00079-9.

Madrau, M. A., Pisicopo, A., Sanguinetti, A. M., Del Caro, A., Poiana, M., Romeo, F. V., \& Piga, A. (2009). Effect of drying temperature on polyphenolic content and antioxidant activity of apricots. European Food Research and Technology, 228(3), 441-448. http://dx.doi. org/10.1007/s00217-008-0951-6.

Manzocco, L., Calligaris, S., Mastrocola, D., Nicoli, M. C., \& Lerici, C. R. (2001). Review of non-enzymatic browning and antioxidant capacity in processed foods. Trends in Food Science \& Technology, 11(9-10), 340-346. http://dx.doi.org/10.1016/S0924-2244(01)00014-0.

Maskan, M. (2000). Microwave/air and microwave finish drying of banana. Journal of Food Engineering, 44(2), 71-78. http://dx.doi. org/10.1016/S0260-8774(99)00167-3.

Melgarejo, P., Calín-Sánchez, A., Carbonell-Barrachina, Á. A., MartínezNicolás, J. J., Legua, P., Martínez, R., \& Hernández, F. (2014). Antioxidant activity, volatile composition and sensory profile of four new very-early apricots (Prunus armeniaca L.). Journal of the Science of Food and Agriculture, 94(1), 85-94. http://dx.doi.org/10.1002/ jsfa.6201. PMid:23633390.

Morales, F. J., \& Jiménez-Pérez, S. (2004). Peroxyl radical scavenging activity of melanoidins in aqueous systems. European Food Research and Technology, 218, 515-520. http://dx.doi.org/10.1007/s00217004-0896-3.

Mundada, M., Hathan, B. S., \& Maske, S. (2010). Convective dehydration kinetics of osmotically pretreated pomegranate arils.
Biosystems Engineering, 107(4), 307-316. http://dx.doi.org/10.1016/j. biosystemseng.2010.09.002.

Nicoli, M. C., Anese, M., \& Parpinel, M. (1999). Influence of processing on the antioxidant properties of fruit and vegetables. Trends in Food Science \& Technology, 10(3), 94-100. http://dx.doi.org/10.1016/ S0924-2244(99)00023-0.

Nordic Committee on Food Analysis - NMKL. (2007). Trace elements - As, Cd, Hg, Pb and other elements: determination by ICP-MS after pressure digestion: NMKL186, 2007. Oslo. Retrieved from http:// www.nmkl.org/index.php/en/?option=com_zoo\&task=item\&item _ $\mathrm{id}=359$ \&Itemid=319\&lang=en

Özkan, M. (2001). Studies on desulfiting methods of dried apricots (Master's thesis). Ankara University, Ankara.

Özkan, M., Kırca, A., \& Cemeroglu, B. S. (2003). Effect of moisture content on CIE color values in dried apricots. European Food Research and Technology, 216, 217-219.

Özler, A., Karakus, E., \& Pekyardımcı, S. (2008). Purification and biochemical characteristics of pectinesterase from Malatya apricot (Prunus armeniaca L.). Preparative Biochemistry \& Biotechnology, 38(4), 358-375. http://dx.doi.org/10.1080/10826060802325469. PMid:18800299.

Penicaud, C., Achir, N., Dhuique-Mayer, C., Dornier, M., \& Bohuon, P. (2011). Degradation of b-carotene during fruit and vegetable processing or storage: reaction mechanisms and kinetic aspects: a review. Fruits, 66(6), 417-440. http://dx.doi.org/10.1051/fruits/2011058.

Prabhanjan, D. G., Ramaswamy, H. S., \& Raghavan, G. S. V. (1995). Microwave-assisted convective air drying of thin layer carrots. Journal of Food Engineering, 25(2), 283-293. http://dx.doi.org/10.1016/02608774(94)00031-4.

Rababah, T. M., Al-Mahasneh, M. A., Kilani, I., Yang, W., Alhamad, M. N., Ereifej, K., \& Al-U'datt, M. (2011). Effect of jam processing and storage on total phenolics, antioxidant activity and anthocyanins of different fruits. Journal of the Science of Food and Agriculture, 91(6), 1096-1102. http://dx.doi.org/10.1002/jsfa.4289. PMid:21254073.

Radi, M., Mahrouz, M., Jaouad, A., Tacchini, M., Aubert, S., Hugues, M., \& Amiot, M. J. (1997). Phenolic composition, browning susceptibility, and carotenoid content of several apricot cultivars at maturity. Horticultural Science, 32, 1087-1091.

Ramakrishnan, T. V., \& Francis, F. J. (1973). Color and carotenoid changes in heated paprika. Journal of Food Science, 38(1), 25-28. http://dx.doi.org/10.1111/j.1365-2621.1973.tb02767.x.

Rice-Evans, C. A., Miller, N. J., \& Paganga, G. (1997). Antioxidant properties of phenolic compounds. Trends in Plant Science, 2(4), 152-159. http://dx.doi.org/10.1016/S1360-1385(97)01018-2.

Rodriguez-Amaya, D. B. (2010). Quantitative analysis, in vitro assessment of bioavailability and antioxidant activity of food carotenoids: a review. Journal of Food Composition and Analysis, 23(7), 726-740. http://dx.doi.org/10.1016/j.jfca.2010.03.008.

Ruiz, D., Egea, J., Tomas-Barberan, F. A., \& Gil, M. I. (2005). Carotenoids from new apricot (Prunus armeniaca L.) varieties and their relationship with flesh and skin color. Journal of Agricultural and Food Chemistry, 53(16), 6368-6374. http://dx.doi.org/10.1021/ jf0480703. PMid:16076120.

Sablanı, S. S. (2006). Drying of fruits and vegetable: retention of nutritional/functional quality. Drying Technology, 24(2), 123-135. http://dx.doi.org/10.1080/07373930600558904.

Sağırlı, F., Tagı, S., Ozkan, M., \& Yemis, O. (2008). Chemical and microbial stability of high moisture dried apricots during storage. Journal of the Science of Food and Agriculture, 88(5), 858-869. http:// dx.doi.org/10.1002/jsfa.3162. 
SAS Institute - SAS. (2005). Statistical discovery from SAS Institute Inc. Cary.

Sass-Kiss, A., Kiss, J., Milotay, P., Kerek, M. M., \& Toth-Markus, M. (2005). Differences in anthocyanin and carotenoid content of fruits and vegetables. Food Research International, 38(8-9), 1023-1029. http://dx.doi.org/10.1016/j.foodres.2005.03.014.

Ścibisz, I., \& Mitek, M. (2007). Antioxidant activity properties of high bush blueberry fruit cultivars. Food Science and Technolology, 10(4), 34.

Suna, S., Tamer, C. E., Incedayı, B., Ozcan Sinir, G., \& Copur, O. U. (2014). Impact of drying methods on physicochemical and sensory properties of apricot pestil. Indian Journal of Traditional Knowledge, $13,47-55$.

Sunjka, P. S., Rennie, T. J., Beaudry, C., \& Raghavan, G. S. V. (2004). Microwave-convective and microwave-vacuum drying of cranberries: a comparative study. Drying Technology, 22(5), 1217-1231. http:// dx.doi.org/10.1081/DRT-120038588.
United States Department of Agriculture Agricultural Research Service - USDA, National Nutrient Database for Standard Reference Release 28. (2014). Basic Report 09021: apricots, raw. Beltsville. Retrieved from http://ndb.nal.usda.gov/ndb/foods/show $/ 2140$ ?fgcd $=\& m a n u=\& l f a$ cet $=\&$ format $=\&$ count $=\& \max =35 \&$ offset $=\&$ sort $=\&$ qlookup $=09021$

William, B., Cuvelier, E., \& Berset, C. (1995). Use of a free radical method to evaluate antioxidant activity. Lebensmittel Wissenschaft Technology, 28(1), 25-30. http://dx.doi.org/10.1016/S0023-6438(95)80008-5.

Zhang, D., \& Hamauzu, Y. (2004). Phenolics, ascorbic acid, carotenoids and antioxidant activity of broccoli and their changes during conventional and microwave cooking. Food Chemistry, 88(4), $503-$ 509. http://dx.doi.org/10.1016/j.foodchem.2004.01.065.

Zhang, M., Tang, J., Mujumdar, A., \& Wang, S. (2006). Trends in microwave related drying of fruits and vegetables. Trends in Food Science \& Technology, 17(10), 524-534. http://dx.doi.org/10.1016/j. tifs.2006.04.011. 